\title{
Nutraceutical Properties of Milk Fat Globular Membrane
}

\author{
Korry J. Hintze, Dallin Snow, Ian Burtenshaw and Robert E. Ward \\ Utah State University, \\ USA
}

\section{Introduction}

Milk fat globule membrane (MFGM) is a protein-lipid biopolymer that originates from the apical surface of mammary epithelial cells and surrounds fat globules in milk. During milk synthesis, fat droplets originate in the endoplasmic reticulum and travel directly to the cell's apical surface. As they travel from the epithelial cells into the alveolar lumen, they pass through the apical membrane and are encapsulated in the plasma membrane complete with the exterior glycocalyx resulting in discrete globules. These milk fat globules have a nonpolar lipid core composed primarily of triglycerides that is surrounded by the MFGM which contains both membrane polar lipids and glycoproteins.

While MFGM is in all dairy products containing milk fat, it is especially enriched in churn buttermilk, a co product of butter production. When milk fat is churned, the membrane surrounding the fat globules is disrupted, and the free fat released from the globules coalesces. This process ultimately results in a solid fat phase, butter, and an aqueous phase, also known as churn buttermilk. This material, buttermilk, has a long history of anecdotal health-promoting associations, yet it does not currently generate any added value in the market place for delivering nutritional benefit. MFGM has recently been shown in lipidomic and proteomic characterizations to have an interesting carbohydrate, lipid and protein profile. The phospholipids and membrane glycoproteins found in MFGM likely interact extensively with the gut epithelia during digestion, both physically and biochemically. Moreover, MFGM has a relatively high concentration of sphingolipids, which in purified form have been demonstrated to be protective against colon cancer.

The unique composition of MFGM has led to the idea that it may have remarkable nutraceutical properties, however, few studies have tested this hypothesis. Recent studies from our laboratory have demonstrated that dietary MFGM improves gut barrier function in cell and animal models and is protective against colon cancer in a rodent model. In this chapter we will discuss the isolation, composition, biochemical properties and intestinal health promoting effects of the biopolymer MFGM.

\subsection{Milk fat globule membrane}

The role of milk in biology is to nourish infant mammals and to provide vigor, while not overtaxing the biosynthetic capacity of the mother. This functionality has been refined and developed over time via evolutionary selective pressure. Like much of molecular evolution, components of mammalian milks have been repurposed from other functions in biology, 
and the rationale for this is often not clear. While the nutritive value of milk has long been recognized from a compositional perspective, research into the nutritional functionality of milk components has consistently revealed novel pleiotropic beneficial effects which go beyond simple nutrient content (2002; Ward and German 2004; Ward et al. 2004). As unnecessary components would likely be selected against over time, it is hard to imagine there is much that is in milk that would not be interesting from a nutritional perspective. For example, while casein and whey proteins are each recognized as good sources of essential amino acids, current studies are finding novel peptides, which are produced during digestion of these proteins, which positively affect health beyond delivery of amino acids. One interesting, yet underappreciated dairy-derived ingredient is the milk fat globular membrane. Milk fat has a complex native structure which is the result of a novel synthesis and secretion process (reviewed in (Ward, German, and Corredig 2005)). Milk triglycerides are synthesized and/or assembled in the endoplasmic reticulum (ER) of the lactating epithelial cell, and after budding off, are transported to the apical surface of the cell complete with a monolayer of polar lipids derived from the ER. As the fat droplets reach the surface of the cell they pass through the apical membrane and in the process are coated in a bilayer of cell surface membrane. The result of this process is that all native milk fat droplets contain 3 layers of polar membrane lipids, and the surface of the droplets has the molecular characteristics of epithelia. In human, bovine, caprine and ovine milks (the only ones reported), fat globules are present in a bimodal distribution with the diameter of the small globules centered at roughly $0.4 \mu \mathrm{m}$ and the larger at about $3 \mu \mathrm{m}$ (Figure 1). Based on this size distribution, Ruegg and Blanc have estimated that there is up to $500 \mathrm{~cm}^{2}$ of membrane surface area in one $\mathrm{ml}$ of milk (Ruegg and Blanc 1981). A scanning electron micrograph of native milk fat globules (left) and MFGM recovered from buttermilk via ultrafiltration (right) is shown Figure 2. Because each fat globule is enrobed in a coating of apical membrane from the lactating epithelial cell, the outside surface is covered in glycocalyx. Interestingly, when this material is removed from the fat globules, it may be recovered in a form which appears to be an empty sac of membrane. A scanning electron micrograph of MFGM isolated via an ultrafiltration process is shown on the right side of Figure 2.
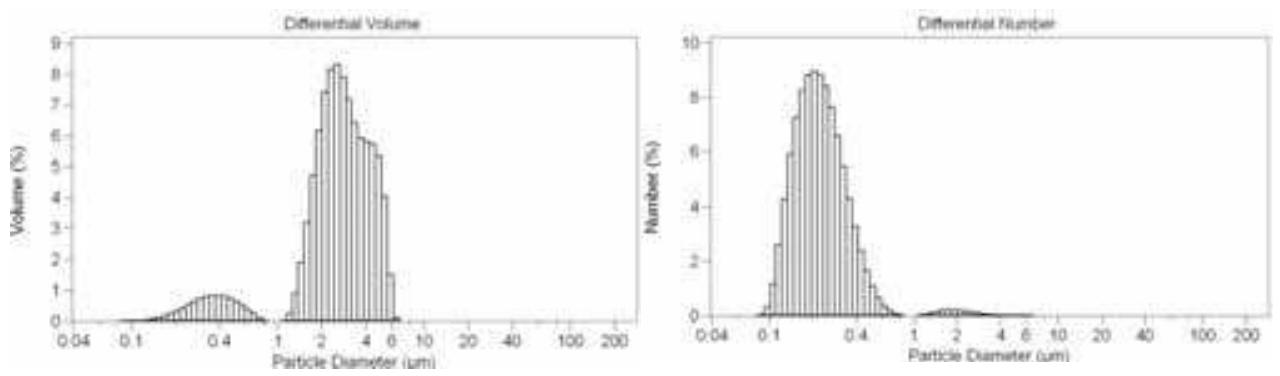

Fig. 1. Distribution of milk fat droplets by volume (left) and number (right) measured with laser diffraction particle size analyzer. The majority of the fat in milk is present in the large fat droplets (left), while the majority of the droplets are less than $1 \mu \mathrm{m}$ in diameter (right).

When milk fat is churned, as in the production of butter, the membrane surrounding the fat globules is disrupted and free fat released from the globules coalesces. This process ultimately results in a solid fat phase (butter) and an aqueous phase, also known as churn buttermilk. This material (buttermilk) has a long history of anecdotal health-promoting 
associations, yet it does not currently generate any added value in the market place for delivering nutritional benefit. As large quantities are produced in the US annually, and as it gets spray dried and used as an ingredient in many products, it seems worthy of investigating potential benefits its consumption might confer. In November of 2008, 7.2 M lbs of (dried) buttermilk were produced in the US (http://www.ams.usda.gov). As approximately $8 \%$ of buttermilk is MFGM (Astaire et al. 2003), annual production of this material is estimated to be roughly $7 \mathrm{M}$ lbs.

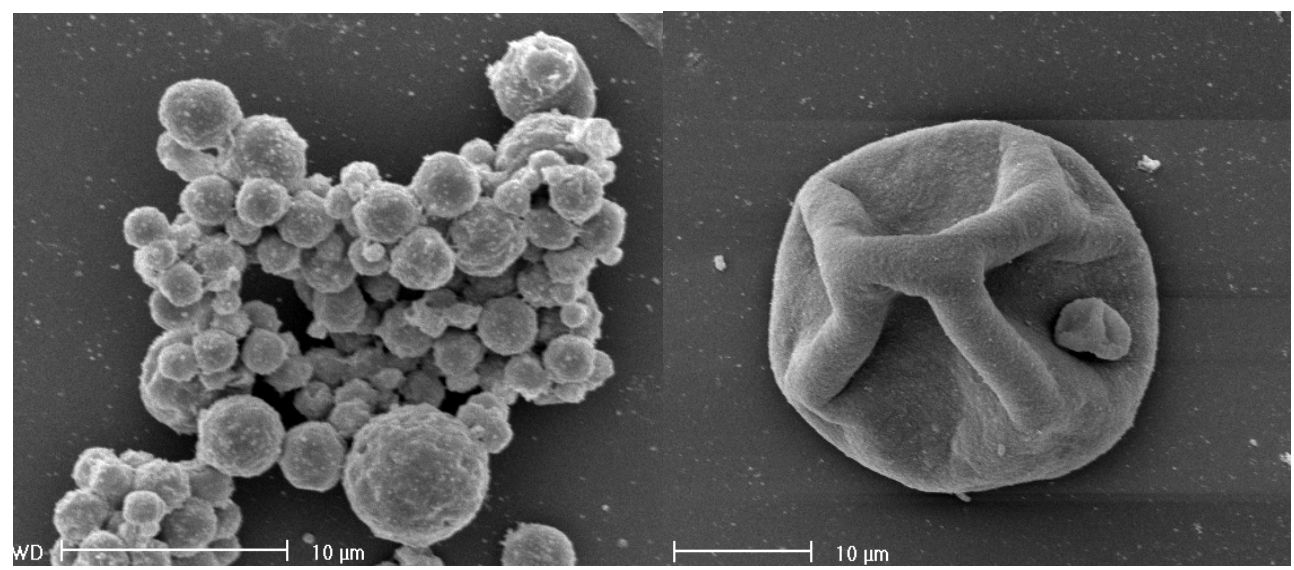

Fig. 2. Scanning electron micrographs of native milk fat globules (left) and milk fat globular membrane isolated from buttermilk with ultrafiltration (right).

\section{MFGM composition}

As a result of the synthetic process that produces it, MFGM has an interesting profile of carbohydrates, lipids and proteins. The main lipid and protein constituents are listed in Table 1 and were, for the most part, discovered and characterized using basic protein and lipid analysis techniques. While this list of lipids is in the table is fairly comprehensive, the proteins listed are the main components that have been studied using one dimensional gel electrophoresis which is not particularly sensitive. However, recently several groups have begun to detect many more proteins present at trace levels using proteomics techniques. For example, Reinhart and Lippolis (2006) detected up to 120 proteins using a combination of one dimensional SDS gel electrophoresis and micro-capillary HPLC nanospray-tandem mass spectrometry of tryptic digests from the gel. Of the proteins detected, $71 \%$ were membrane associated and the balance were identifies as either cytoplasmic proteins or secreted proteins. The molecular function of the proteins identifies were membrane/protein trafficking (23\%) cell signaling (23\%), unclassified (21\%), fat metabolism/transport $(9 \%)$, protein synthesis/folding (7\%), immune proteins $4 \%$ ) and milk proteins (2\%). Fong et al (2007) investigated both protein and lipid constituents of the MFGM using mass spectrometry. In this study, eight novel proteins were detected in the MFGM and a more complete analysis of the lipid fraction was reported. A third group used direct liquid chromatography-tandem mass spectrometry (LC-MS) and 2D gel electrophoresis followed by matrix assisted laser desorption ionization-time-of-flight mass spectrometry (MALDITOF) of individual protein gel spots to characterize minor proteins (Smolenski et al. 2007). 
In total, they identified 95 distinct gene products at least 15 of which were involved in host defense.

\begin{tabular}{|lllll|}
\hline Lipids & $\%$ & Polarlipids & $\%$ & Proteins \\
\hline Triacylglycerols & 62 & Sphingomyelin & 22 & Mucin 1 \\
Diacylglycerols & 9 & Phosphatidylcholine & 36 & Xanthine oxidoreductase \\
Monoacylglycerols & Trace & Phosphatidylethanolamine & 27 & PAS III \\
Sterols & $0.2-2$ & Phosphatidylinositol & 11 & CD 36 \\
Sterol esters & $0.1-0.3$ & Phosphatidylserine & 4 & Butyrophilin \\
Free Fatty acids & $0.6-6$ & Lysophosphatidylcholine & 2 & PAS 6/7 \\
Hydrocarbons & 1.2 & & & Adipophilin \\
Phospholipids & $26-31$ & & & Fatty acid binding protein \\
\hline
\end{tabular}

Table 1. Major Components of MFGM (Adapted from (Keenan and Patton 1995))

In these initial studies, the analyses were all qualitative and no attempt was made to quantify specific proteins. Recently, Fong and Norris (2009) utilized the absolute quantification (AQUA) technique, a proteomic to explore the abundance of specific MFGM proteins. In their analysis, six proteins (fatty acid binding protein, butyrophilin, PAS 6/7, adipophilin, xanthine oxidase and mucin 1) were measured and have all been long known to be components of MFGM (Table 1). Although their absolute results appear to depend somewhat on how the material was isolated, the relationship among the major proteins appears to be stable. According to their results, the amount of these proteins are present in the membrane in decreasing order PAS 6/7, butyrophilin, xanthine oxidase, mucin 1 , adipophilin, and fatty acid binding protein. In a somewhat related study, Affolter et al (2010) compared proteomic profiles of a whey protein isolate with buttermilk powder. Using a shotgun proteomics approach, they identified 244 proteins in the whey powder and 133 in the buttermilk isolate. In addition, they conducted a relative quantitative comparison of the top 34 proteins identified.

While most studies of MFGM proteins have focused on membranes isolated from either human or bovine milk, recently analyses of both goat and sheep MFGM have been reported. Cebo et al (2010) used one dimensional SDS-PAGE to investigate goat MFGM. In their analyses using peptide mass fingerprinting of proteins from the electrophoresis gel they detected many of the same proteins listed in Table 1 (mucin 1, xanthine oxidase butyrophilin, lactadherin and adipophilin). As for analysis of MFGM isolated from sheep milk, Pisanu et al (2011) used SDS-PAGE combines with tandem LC-MS to characterize the protein content of this biopolymer. In their analysis, 140 unique proteins were identified and their relative abundance measured. Of the components detected, gene ontology classifiers indicated that the majority were associated with membrane and vesicular trafficking $(\sim 35 \%)$, protein synthesis, binding and folding $(\sim 15 \%)$, enzymatic activity $(\sim 15 \%)$ and cell signaling $(\sim 12 \%)$. Other minor activities mediated by these proteins were immune function $(\sim 8 \%)$ and fat transport/metabolism $(\sim 7 \%)$. The most abundant proteins were butyrophilin, xanthine oxidase, lactadherin and adipophilin.

\section{Isolation of MFGM}

MFGM is a minor component of milk fat and in most dairy products. However, in modern dairy operations it is produced as a byproduct in preparation of both cheese and butter. 
Nevertheless, to obtain it in a relatively concentrated form it must be separated from other components. Isolation of MFGM may be conducted on a lab scale for detailed anayses and/or functional characterization. In addition, in recent years several groups have published methods for isolation of MFGM from byproducts such as cheese whey and churn buttermilk. In work conducted in our laboratories MFGM is isolated using a combination of casein precipitation and ultrafiltration. The process begins with raw milk and cream is collected via centrifugation. The cream is churned in a Waring Blender for 30 minutes at $4^{\circ} \mathrm{C}$. The resulting butter is removed from the buttermilk using filtration through cheese cloth to remove butter particles. To precipitate caseins in the buttermilk the $\mathrm{pH}$ is lowered to 4.6 using acetic acid and the temperature raised to $37^{\circ} \mathrm{C}$ for 30 minutes with constant stirring. Precipitated caseins are removed via centrifugation at $1000 \times \mathrm{g}$ for $30 \mathrm{~min}$. The $\mathrm{pH}$ is readjusted to 6.7 with $1 \mathrm{M} \mathrm{NaOH}$, and the buttermilk is ultrafiltered with a Millipore Prep/Scale benchtop unit using a MWCO filter of $300 \mathrm{kD}$. The buttermilk is diafiltered for several hours at $4^{\circ} \mathrm{C}$, until 6 volumes of the starting material are collected as permeate. The retained material, or retentate, issubsequently freeze dried.

In the past several years several groups have developed methods to isolate MFGM from both cheese whey and buttermilk. Astaire et al (2003) used a two step process to produce a MFGM isolate enriched in phospholipids. In the first step MFGM was subjected to microfiltration with a 0.8 micron pore size filter. To remove nonpolar lipids the resulting material was then subjected to supercritical fluid extraction. One drawback of isolating MFGM from buttermilk with microfiltration is that casein micelles are also retained in the process. Corredig et al (2003) addressed this problem by adding sodium citrate to the process, which facilitates the dissolution of the micelles and their removal in the permeate. Other groups have shown that MFGM may also be isolated from other dairy products, such as butter serum. For example, Rombaut et al (2006) used microfiltration with both sodium citrate and ethanol additions to facilitate the removal of casein micelles and reported obtaining a relatively pure product. This group has also demonstrated that a similar process is effective for recovering MFGM from acid buttermilk cheese whey (Rombaut, Dejonckheere, and Dewettinck 2007). In an improvement on this process, it was found that increased recoveries of MFGM can be achieved via a process termed thermocalcic aggregation (Rombaut and Dewettinck 2007). This process utilizes $\mathrm{pH}$ adjustments as well as heat and added calcium to facilitate the precipitation of MFGM aggregates. More recently, Damodaran (2010) showed that zinc is a more effective divalent cation than ether magnesium or calcium in causing MFGM components to aggregate.

\section{Interactions of MFGM with microbiota}

The large surface area of MFGM and its glycocalyx exterior suggests there may some interaction with the human microbiota and several studies have focused on this interaction. For example, Clare et al (2008) utilized an in vitro screening assay to test for antimicrobial activity of intact MFGM and peptide hydrolysates against several human pathogens and commensal bacteria. Interestingly, they found there was some activity against Salmonella enteric Typhimurium and Pseudomonas fluorescens that the results were variable depending on the growth media selected. They attributed these differential results to the presence of purines in the active media, which can be used by the xanthine oxidase of MFGM to generate peroxide. Other studies have focused on the interaction of microbes with the surface of MFGM. For example, Brisson et al (2010) characterized the relationship between 
Lactobacillus reuteri and the surface of MFGM. According to their study, binding of $L$ reuteri to the surface of MFGM was dependent on the hydrophobicity of the bacteria and was correlated with a cell surface protein. In addition, this study involved determining binding force measurements which were generated with optical tweezers. Other studies have investigated the effects of dietary MFGM on the colonic microbiota. For example, the ability of MFGM to inhibit intestinal $\beta$-glucuronidase activity was measured by Ito et al. (1993). This enzyme is a product of colonic enterobacteria, and when present in the colon has the ability to activate carcinogenic precursors into carcinogens (Simon and Gorbach, 1984). However, this activity is inhibited by sialoglycoproteins from porcine salivary glands (Sakamoto, 1975). To test the hypothesis that sialoglycoproteins from bovine milk might provide this benefit, Ito et al. (1993) conducted in vitro enzymatic assays and in vivo feeding studies with mice. In the enzyme assay, $0.2 \% \mathrm{w} / \mathrm{v}$ MFGM inhibited $\beta$-glucuronidase activity on the substrate p-phenolphthalein $\beta$-D-glucuronide by $90 \%$, while $\mathrm{K}$-casein at the same concentration inhibited the reaction by $35 \%$. To determine whether this activity would survive gastrointestinal transit, the authors fed mice diets supplemented with $5 \%, 10 \%$, and $20 \%$ MFGM for five days, and measured $\beta$-glucuronidase activity in feces. The $5 \%$ and $10 \%$ diets caused roughly a $15-20 \%$ inhibition of fecal $\beta$-glucuronidase activity, whereas the effect rose to $50 \%$ when $20 \%$ MFGM was added to the standard diet.

\section{In-Vitro studies conducted with MFGM}

\subsection{In vitro MFGM digestions}

One model in which to study the bioactivities of MFGM is with cells in culture. However, treating cultured cells with a complex material isolated from milk is not necessarily physiologically relevant, and pursuing the effects of the digestion process on the integrity of MFGM components is warranted. Using a method adapted from Adkins and Lonnerdal, in vitro proteolysis of MFGM was conducted by incubating the material with porcine pepsin for 30 minutes at a $\mathrm{pH}$ of 3 , and then raising the $\mathrm{pH}$ to 7 and continuing the process with porcine pancreatin (Adkins and Lonnerdal 2003). To characterize the effects of the proteolysis, aliquots of the digestion process were seperated using SDS-PAGE with 4-20\% gels, stained the proteins with silver reagent (results not shown). Based on the peptide migration patterns in the gels from before and after digestion, very little of the native proteins escape digestion by gut proteases.

While the porcine pancreatin used in the proteolysis experiment also contains pancreatic lipase, there is no commercial source for gastric lipase. However, von Ebner glands of rat tongues are a rich source, and this enzyme was isolated according to the method of Hamosh (Hamosh, Ganot, and Hamosh 1979). Lipolytic activity was confirmed using paranitrophenyl palmitate (Gupta, Rathi, and Gupta 2002). MFGM was adjusted to a pH of 3.0 with phosphate buffer, and crude isolate of rat tongues was added. The reaction was allowed to proceed for 30 minutes, the $\mathrm{pH}$ was raised to 7.0, and pancreatin was added along with $\mathrm{CaCl}_{2}$ and bile salts according to the method of Bernback (Bernback, Blackberg, and Hernell 1990). The reaction was allowed to proceed for 1 hour and then terminated by submerging the sample in a $90^{\circ} \mathrm{C}$ water bath for 30 minutes. Samples were freeze dried, lipids extracted by the method of Folch (Folch, Lees, and Sloane Stanley 1957), and separated using thin layer chromatography. Lipids were visualized by spraying plates with cupric sulfate, and heating to $180^{\circ} \mathrm{C}$ for 20 minutes.

It is clear in left side of Figure 3 that the lipase treatment of MFGM causes significant degradation of the polar lipids, and the majority of this activity was mediated by the 
pancreatin digestion. In addition, on the right side of the figure a second separation of lipid classes (triglycerides, diglycerides, monoglycerides cholesterol esters, free fatty acids and phospholipids) indicated that the majority of triglycerides were degraded as well. Of significant interest are the two boxes superimposed over Lane 4 . The lower box is consistent with the mobility of lysophospholipids using this solvent system, whereas the top band is probably phosphatidic acid. Both of these species have demonstrated bioactivity. One other interesting feature of these results is that the sphingolipids do not appear to be affected by the digestion process.

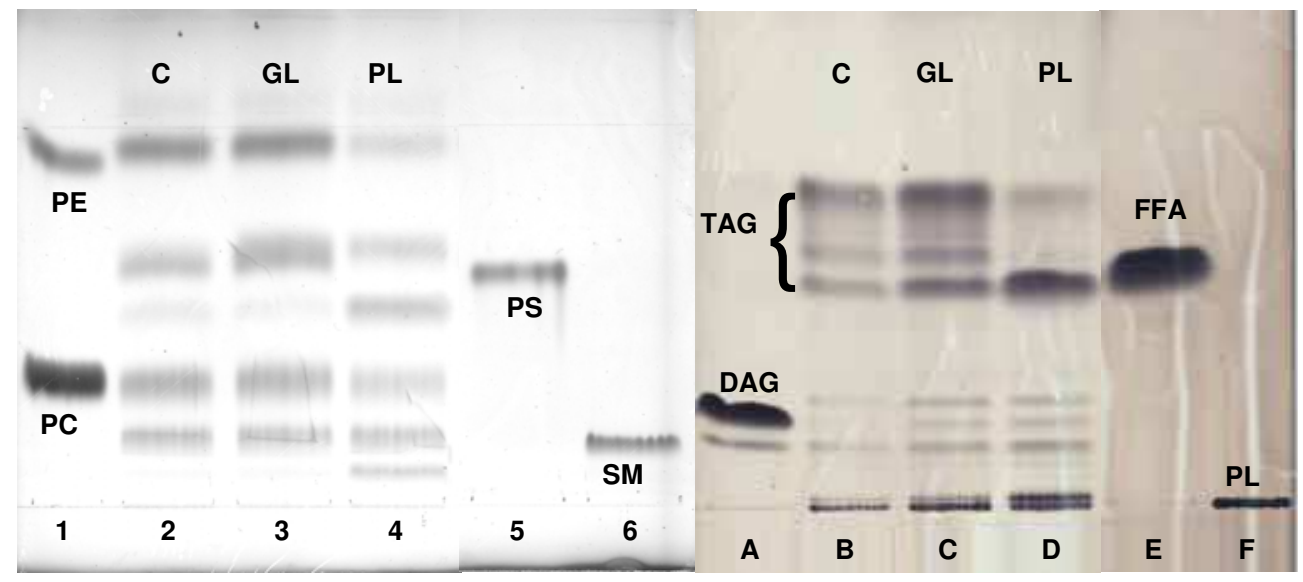

Fig. 3. Results of lipolysis experiment indicate in vitro treatment of MFGM with lipases causes significant digestion of the polar lipids (left) and lipid clases (right). Lipids were isolated by chloroform:methanol extraction, and separated using thin layer chromatography. Lane designations (left): 1) phophatidylcholine (PC) and phosphatidylethanolamine (PE) standards, 2) MFGM, 3) MFGM treated with gastric lipase $(\mathrm{GL}), 4)$ MFGM treated with GL then pancreatic lipase (PL), 5) phosphatidyl serine standard, 6) sphingomyelin standard. Boxes in Lane 4 are consistent with lipolytic generation of lysophospholipids (bottom) and phosphatidic acid (top). Lane designations (right): A) diglyceride (DAG) standard, B) MFGM, C) MFGM treated with GL, C) MFGM treated with GL than PL, E) Free fatty acid standard (FFA) and F) phospolipid standard. It is clear from Lane $\mathrm{H}$ that triglycerides and significantly degraded into free fatty acids, and a new band appears above the phospholipids which, based on mobility, is likely lysophospholipids.

\subsection{Studies in cell culture}

To understand the interaction of MFGM with the gut epithelia during digestion, studies with cultured epithelial cells have been used to characterize this relationship. Consequently, studies with cultured epithelial cells are an interesting system in which to characterize molecular events resulting from the interaction between MFGM and the gut. To probe this interaction, we have developed methods to isolate MFGM, to subject it to an in vitro digestion as well as to use it as a treatment for the epithelial cells.

To investigate potential bioactive effects of the MFGM on gut integrity genome wide expression analysis was conducted using the Caco- 2 model of cultured epithelial cells. MFGM was added to culture media at $1 \mathrm{mg} / \mathrm{ml}$ which was calculated to mimic the 
concentration in milk. MFGM was reconstituted in culture media and confluent cells were treated for 24 hours. mRNA was isolated and cleaned up with a commercial kit, and analyzed using the Illumina whole genome gene expression system with the human-6 v2 chip which was conducted by Genome Quebec. Gene expression of MFGM treated cells was compared to controls cells (no MFGM). Triplicate samples were run for both MFGM treatment and controls.

Data was analyzed using Flex Array, a proprietary software program developed by Genome Quebec. All replicates were normalized, and several statistical programs were run to determine genes that were differentially expressed in response to MFGM (Empirical Bayes, Significance Analysis of Microarrays, 2 sample Bayes algorithm). Surprisingly, of the roughly 47,000 features on the array, very few genes were differentially regulated using the limits of a 2 fold change and a significance level of $\mathrm{p}<0.05$, and agreement was good between algorithms. The majority of the genes identified were metallothioneins (MT), which code for small molecular weight, cystein-rich proteins with redox and metal binding activities. MTs are induced in the liver by a range of metals, and in the gut and pancreas they respond to zinc status (Coyle et al. 2002).

MTs are thought to confer protection from heavy metal exposure and oxidative damage, and the coordinate expression of several isoforms in our cell system raised the possibility that MFGM treatment of the cells may have led to toxic exposure of heavy metals, or perhaps may have induced oxidative stress. Alternatively, we hypothesized that MFGM may be rich in zinc, and that induction of MT genes was part of mechanisms by which this metal is delivered in milk. In support of the oxidative stress hypothesis, one of the main MFGM proteins, xanthine oxidoreductase (XOR) can catalyze the formation of reactive oxygen (ROS) and nitrogen species (RNS), and is thought to be part of the innate immune system (Vorbach, Capecchi, and Penninger 2006). Perhaps not surprisingly, XOR has been implicated as a pathological factor in gut damage induced by ischemia/reperfusion injury via the generation of ROS and RNS (Blikslager, Roberts, and Argenzio 1999).

These findings compelled us to determine the metal composition of the MFGM we isolated. To achieve this end, $200 \mathrm{mg}$ of MFGM was wet ashed by successive digestion with nitric acid and hydrogen peroxide and analyzed in a Thermo Electron Iris Advantage Inductivelycoupled plasma (ICP) spectrophotometer in a Utah State core analytical facility. Trace metals which were above the detection limit are listed in Table 2. From the results we have concluded that MTs are probably not induced by heavy metal contaminants of MFGM, which left the possibility the effect was due to oxidative stress or due the relatively high concentration of zinc. As we moved forward, we kept in mind these two possibilities, as is discussed below.

\begin{tabular}{ccccccc}
\hline metal & Ca & Co & Cu & Mg & Ni & Zn \\
\hline Ppm & 880 & 9 & 25 & 246 & 10 & 126 \\
\hline
\end{tabular}

Table 2. Results of trace metal analysis of MFGM using ICP

Treatment of Caco-2 cells with digested MFGM resulted in the differential regulation of only 62 genes using the limits of a 2 -fold change and a significance level of $p<0.05$. Similar to the treatment with the native MFGM, several MT genes were upregulated, although not as highly. In addition, genes coding for several other zinc binding proteins were induced.

To gain insight into the major cellular processes affected by MFGM treatment, an online tool for pathway analysis of microarray data 
(http://www.pantherdb.org/tools/genexAnalysis.jsp) was utilized. This tool uses gene expression data to indicate whole sets of genes whose regulation would be predicted to be affected by the treatment, and generates statistical p-values indicating the likelihood the effect is due to chance. The results of the pathway analysis with the digested MFGM are listed in Table 3. According to the analysis, several pathways appear to be affected by the treatment, and the majority are downregulated. Two interesting pathways affected, in terms of our data, are those involved in histamine and angiotension signaling. The former would suggest the treatment is associated with a reduction in inflammation and the latter with increased blood flow. While these preliminary observations support our overall hypothesis, we have noted some seeming contradictions. For example, some proinflammatory pathways seem to be downregulated while others are upregulated by treatment with MFGM. Nonetheless, due to the large volume of data generated in such studies, analysis is ongoing. Because this data was generated from cultured enterocytes the data must be interpreted with caution; therefore we are eager to adapt this model to whole animals.

\begin{tabular}{lccr}
\hline Pathway & $\begin{array}{c}\text { Number } \\
\text { of genes }\end{array}$ & Change & P-value \\
\hline Histamine H1 receptor mediated signaling pathway & 42 & - & $2.20 \mathrm{E}-03$ \\
\hline Ubiquitin proteasome pathway & 80 & + & $4.13 \mathrm{E}-03$ \\
\hline Blood coagulation & 60 & - & $4.27 \mathrm{E}-03$ \\
\hline Thyrotropin-releasing hormone receptor signaling pathway & 64 & - & $4.62 \mathrm{E}-03$ \\
\hline 5HT4 type receptor mediated signaling pathway & 35 & - & $6.98 \mathrm{E}-03$ \\
\hline 5HT2 type receptor mediated signaling pathway & 71 & - & $1.07 \mathrm{E}-02$ \\
\hline Endogenous_cannabinoid_signaling & 26 & - & $1.09 \mathrm{E}-02$ \\
\hline Alpha adrenergic receptor signaling pathway & 31 & - & $1.15 \mathrm{E}-02$ \\
\hline Proline biosynthesis & 4 & - & $1.36 \mathrm{E}-02$ \\
\hline Huntington disease & 158 & - & $1.40 \mathrm{E}-02$ \\
\hline Angiotensin II-stimulated signaling through & 54 & - & $1.87 \mathrm{E}-02$ \\
\hline G proteins and beta-arrestin & 29 & - & $1.99 \mathrm{E}-02$ \\
\hline Beta3 adrenergic receptor signaling pathway & & c
\end{tabular}

Table 3. Biological pathways predicted to be significantly affected in Caco-2 cells by MFGM subjected to an in vitro digestion process as determined by the free software tool, Panther (Clark et al. 2003). Pathways that are upregulated by treatment are marked with a (+)and those downregulated with a (-).

\subsection{Effects of MFGM on membrane permeability}

Based on the large membrane surface area in milk provided by the MFGM, we hypothesized that this material may have positive effects on the gut epithelia. To test this hypothesis, we conducted a barrier permeability assay with Caco-2 cells. Caco-2 cells were seeded on Corning Transwell membranes inserts $(0.4 \mu \mathrm{M}$ pore size) and placed in 6-well plates creating a bi-cameral chamber. Caco-2 cells were grown for 21 days on membrane inserts to ensure polarization and formation of tight junctions. Culture media was changed every 3 days. As our proteolysis and lipolysis results indicated that MFGM is substantially degraded by the digestion process, we compared the effect of treating cells with material 
resulting from this process, as well as native material. To test the effects of MFGM on membrane integrity, cells were incubated with either: control, $1 \mathrm{mg} / \mathrm{ml} \mathrm{MFGM,} 1 \mathrm{mg} / \mathrm{ml}$ proteolyzed MFGM or $1 \mathrm{mg} / \mathrm{ml}$ lypolozized MFGM for 24 hours. After treatment, the media was changed and mucosal barrier integrity was stressed by the addition of $2 \mathrm{mM}$ EGTA, which has been shown in previous studies to reduce the integrity of tight junctions (Prosser et al. 2004). To determine Caco-2 membrane integrity we measured the flux of phenol red from the upper chamber to the lower chamber which contained media without phenol red. At 2.5 hours, $50 \mu \mathrm{l}$ of media was sampled from the lower chamber and the phenol red concentration was determined by spectroscopy using the method of (Jovov, WIlls, and Lewis 1991). Our results, shown in Figure 4, indicate that MFGM reduced permeability in the control (no EGTA) as well as the treated cells. Furthermore, this effect was amplified when the MFGM was previously subjected to the in vitro digestion process described above.

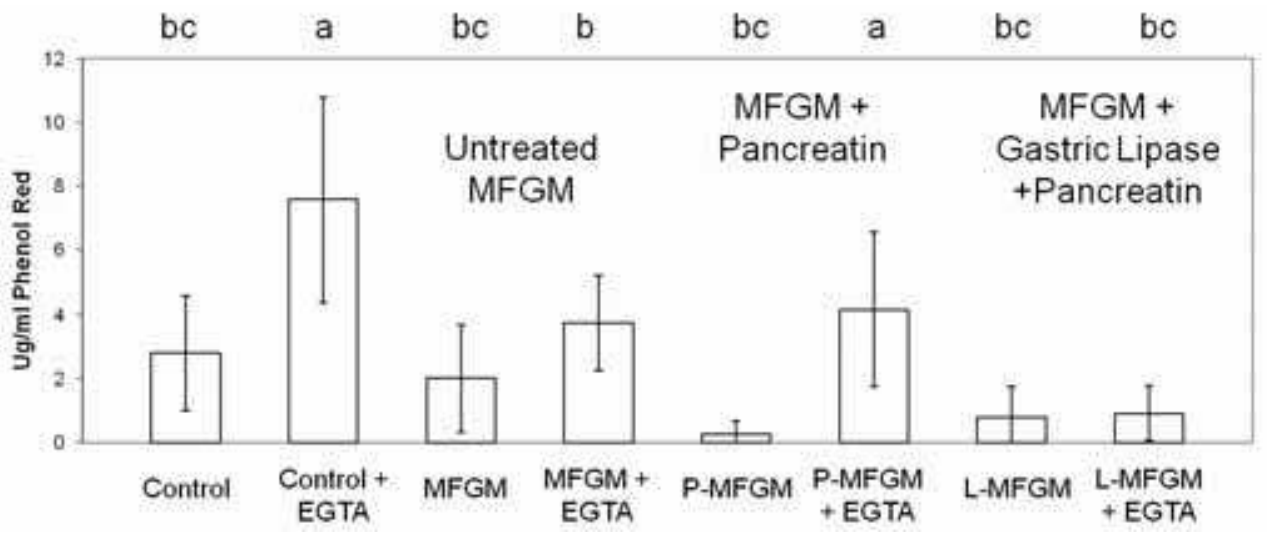

Fig. 4. Results of membrane permeability study. Caco-2 cells were grown to polarization, and treated with either: control (no MFGM), $1 \mathrm{mg} / \mathrm{ml}$ MFGM, $1 \mathrm{mg} / \mathrm{ml}$ proteolyzed MFGM (P-MFGM), or $1 \mathrm{mg} / \mathrm{ml}$ lipolyzed (MFGM) for 24 hours. After treatment, media was changed and a cohort of cells were stressed by the addition 2 mM EGTA (a known stressor of barrier integrity) for 2 hours. Media in the upper chamber contained phenol red, whereas the media in the lower chamber did not. The y-axis represents phenol red concentration, which is indicative of membrane leakiness. It is clear that application of EGTA to the control cells increases permeability, and MFGM treatment reduces this effect. Interestingly, protease and lipase treated MFGM reduces permeability to a greater extent. Differently letter columns are statistically different $(p<0.05$.)

\subsection{Summary}

To summarize our cell culture work, we have demonstrated that MFGM treatment of Caco-2 cells results in a very specific induction of MT genes. This effect may be due to the zinc concentration (or perhaps $\mathrm{Cu}$ or $\mathrm{Mn}$ ), or perhaps due to the activity of XOR in generating ROS and/or RNS. We have subsequently showed that MFGM is substantially degraded by the digestion process, and that the products of these processes appear to be more efficacious in promoting mucosal integrity in the Caco-2 cell model than native, untreated MFGM. 


\section{MFGM and colon cancer}

Colon cancer is the third most commonly diagnosed cancer in the United States and the second most common cause of cancer-related deaths (Society 2009). Diet is a well recognized contributing factor to the etiology of cancer and may be associated with $35-70 \%$ of the incidence of colon cancer (Doll and Peto 1981). Although various carcinogens are present in foods, their effects may be minor when compared with dietary components that inhibit the cancer process (Doll and Peto 1981). As a consequence, many dietary treatments have been tested specifically for their ability to inhibit colon cancer.

Previous studies have demonstrated that purified sphingolipids, such as sphingomyelin, are protective against colon cancer in animal models (Duan and Nilsson 2009; El Alwani et al. 2006). Sphingolipids are composed of a ceramide core, which in turn, is composed of a sphingosine backbone with a fatty acid covalently bonded via an amide linkage. Several different head groups may be covalently attached to the ceramide, each resulting in a different class of sphingolipid. Examples include sphingomyelin, with a phosphocholine headgroup, glycosphingolipids with one or more monosaccharides in the headgroup and gangliosides, which have at least three sugars in head group including at least one sialic acid. The anticancer activity of sphingolipids is primarily associated with their metabolites, ceramide and sphingosine (Jayadev, Linardic, and Hannun 1994). Ceramide is an important second messenger implicated in various physiological functions, like apoptosis, and has recently been associated with targeting mitochondrial activity in colon cancer cells (Dahm et al. 2008; Dindo et al. 2006). Sphingolipid digestion is slow and occurs along the entire length of both the small intestine and the colon which results in high levels of ceramide and sphingosine in the lumen producing the potentially beneficial effects (Nilsson and Duan 2006). Dietary sphingomyelin and glycosphingolipids isolated from milk have been shown to inhibit chemically induced colon cancer in a mouse model (Dillehay et al. 1994; Schmelz et al. 2000), and administration either before or after tumor initiation reduced tumor formation (Lemonnier et al. 2003).

One significant source of dietary sphingolipids is the milk fat globule membrane (MFGM), a protein-lipid complex that is derived from the apical surface of mammary epithelial cells and surrounds the fat globules in milk. Milk fat globules are composed of a nonpolar lipid core (mainly triglycerides) surrounded by the MFGM, which is composed of phospholipids and membrane glycoproteins (see Table 1 for major components of MFGM). Triglycerides are the dominant lipid class, and account for approximately $98 \%$ of milk fat, while the balance is composed of phospholipids $(0.8 \%)$, diglycerides $(0.3 \%)$, monoglycerides $(0.03 \%)$, cholesterol $(0.3 \%)$, and free fatty acids (0.1\%) (MacGibbon and Taylor 2006).

Because of its unique lipid profile, relative sphingolipid enrichment and widespread availability, MFGM is a good candidate for a colon chemopreventive, bioactive ingredient. MFGM has an interesting profile of carbohydrates, lipids and proteins, and is the most diverse fraction of milk. The unique compositional feature has led to the suggestion that MFGM may have interesting nutraceutical properties (Spitsberg 2005), and several research groups have conducted studies to facilitate its recovery from buttermilk (Astaire et al. 2003; Corredig, Roesch, and Dalgleish 2003; Morin et al. 2007; Morin, Pouliot, and Jimenez-Flores 2006; Rombaut, Dejonckheere, and Dewettinck 2006, 2007; Rombaut and Dewettinck 2007; Spence et al. 2009, 2009)

\subsection{Experimental design}

Although very few studies have been conducted to determine any nutritional benefits of MFGM, some indicate positive effects. A recent study concluded digestion products of 
MFGM may have antimicrobial activity (Clare et al. 2008). Because of its unique biochemical nature, sphingolipid enrichment and resulting putative chemoprotective properties, we investigated whether diets containing MFGM are protective against colon cancer in Fischer344 rats using the aberrant crypt foci (ACF) model. Diets were formulated to differ only in the composition of the fat. The control diet contained $5 \%$ fat provided as corn oil. The MFGM diet also contained 5\% fat, but half of the fat for the MFGM diet was provided as anhydrous milk fat and half was provided as MFGM isolate. MFGM isolate is approximately $60 \%$ triglycerides and $40 \%$ polar lipids. Besides dietary fat source, both diets were identical in macro and micro-nutrients. Experimental diets were fed for 13 weeks and rats were injected with 1,2-dimethylhydrazine (DMH, $25 \mathrm{mg} / \mathrm{kg} \mathrm{BW}$ ) weeks 3 and 4 . After 13 weeks, rats were euthanized, tissues were collected and ACF were scored by light microscopy using the method of (Finley et al. 2001). The Utah State University Institutional Animal Care and Use Committee approved all protocols involving animals.

\subsection{Effect of dietary MFGM on appearance of Aberrant Crypt Foci}

The 1,2-dimethylhydrazine induced ACF model is a well established model of colon cancer and has been used extensively in nutritional studies (Dillehay et al. 1994; Lemonnier et al. 2003; Schmelz et al. 2000; Schmelz et al. 1996; Finley et al. 2001; Pretlow et al. 1992; Tudek, Bird, and Bruce 1989). Rats fed the MFGM $(n=16)$ diet had a significantly reduced number of ACF $(P<0.005)$ compared to the control $(n=17)(20.9 \pm 5.7$ vs. $31.3 \pm 9.5)$ and AMF $(n=16)$ diets $(29.8 \pm 11.4)$, and ACF was not significantly different between control and AMF treatments (Figure 5-A). Dietary treatment had no effect on ACF size (Figure 5-B) nor was there a significant difference in the number of ACF with four or more crypts/focus (data not shown) possibly suggesting that MFGM treatment is more relevant to preventing ACF initiation as opposed to ACF growth progression.

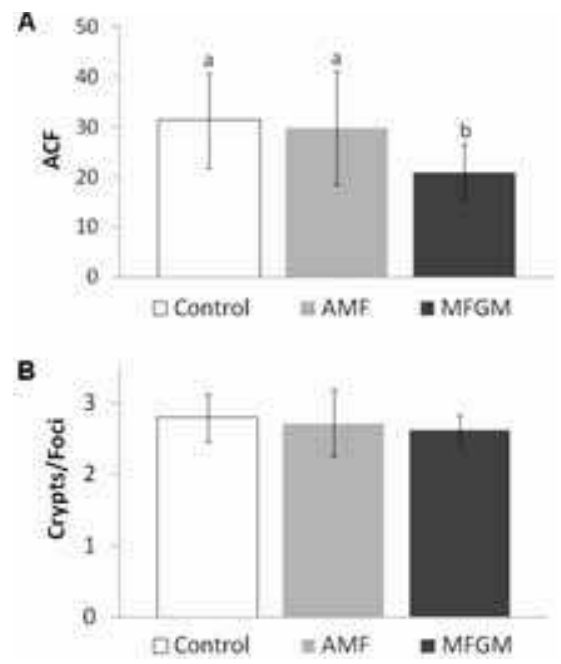

Fig. 5. Effect of experimental diets on (A) 1,2-dimethylhydrazine induced aberrant crypt foci (ACF) and (B) ACF size. Values are means ( $n=17$ control diet, $n=16$ anhydrous milk fat diet, $\mathrm{n}=16$ milk fat globular membrane diet) \pm standard deviation. Significant differences were determined by ANOVA and Fisher's LSD test. Adapted from (Snow et al. 2010) 


\subsection{Effect of dietary MFGM on rat mucosal gene expression}

Out of 21,792 genes, a total of 417, 450, and 321 genes were differentially regulated with significance in the mucosa between the MFGM and control, AMF and control, and MFGM and AMF dietary treatments, respectively. Despite the observation that MFGM treatment decreased ACF compared to both control and AMF; no common gene regulation was observed between MFGM vs. control and AMF.

Although dietary MFGM treatment did not influence the expression of common colon cancer genes; sphingomyelin and MFGM's ability to regulate post-transcriptional gene expression cannot be completely ruled out. A recent study demonstrated that sphingomyelin treatment did not significantly alter mRNA levels but had a significant effect on protein levels of genes critical to the early stages of colon cancer, such as, beta-catenin, connexin- 43 and Bcl-2 (Simon et al. 2009). Our results together with these recent findings suggest that the sphingolipids present in the MFGM may not be regulating transcription but may be regulating specific posttranscriptional events to reverse aberrant expression of individual proteins involved in colon carcinogenesis. Because many of the phospholipids found in MFGM are common second messengers, future studies utilizing pathway analysis and proteomics to examine any relationships between MFGM and relevant metabolic pathways are needed.

\subsection{Summary}

Our results support the hypothesis that diets containing MFGM are protective against colon cancer in Fischer-344 rats, perhaps because of MFGM's high polar lipid content, namely, sphingomyelin. By incorporating MFGM into the diet, animals were provided $(0.11 \% \mathrm{w} / \mathrm{w})$ sphingomyelin. Previous studies using sphingomyelin concentrations ranging from $0.025 \%$ to $0.1 \%$ sphingomyelin (by weight) have clearly shown sphingomyelin's role in the prevention of colon carcinogenesis (Dillehay et al. 1994; Lemonnier et al. 2003; Schmelz et al. 2000; Simon et al. 2009); however many of those studies used a very pure form of isolated sphingomyelin. In this study, the sphingomyelin is in a more practical form or more similar to how it would be incorporated into human diets, and the MFGM contains other important phospholipids such as phosphatidylcholine and phosphatidylethanolamine. One other major difference in the MFGM diet, compared to the control and AMF diets, was the contribution of MFGM proteins. Several of these membrane proteins have been hypothesized to provide biological effects, and we cannot rule out the fact that they may have contributed to the protective effect of the diet. In pilot studies conducted in vitro, we noted that these proteins are extensively proteolyzed by a combination of stomach and pancreatic proteases, but this does not rule out bioactivity mediated by the peptide fragments. Thus, the contribution of these proteins remains unknown. The results of this study demonstrate that MFGM, a readily available byproduct from dairy processing, can be incorporated into diets and is protective against colon cancer.

\section{MFGM and inflammation}

Inflammation causes increased intestinal permeability and gut barrier integrity is compromised leading to dysfunction (Zayat, Lichtenberger, and Dial 2008). While the mechanism of how gut barrier dysfunction occurs is unclear, pro-inflammatory cytokines, such as, IL-4, IL-13, IFN- $\gamma$, and TNF- $\alpha$, have been reported to increase the permeability of intestinal epithelia (Fink 2003; Lewis and McKay 2009; Yajima et al. 2009). Several studies suggest that various milk sphingolipids, including sphingomyelin and gangliosides, 
positively affect the gut by exhibiting a protective effect against colon cancer (Dillehay et al. 1994; Duan and Nilsson 2009; Nilsson and Duan 2006; Schmelz et al. 1996; Schmelz et al. 2000), and other studies have linked sphingolipids and other milk fat fractions containing phospholipids and gangliosides to the inhibition of a pro-inflammatory response and gut barrier protection (Dalbeth et al. 2009; El Alwani et al. 2006; Park et al. 2007; Park et al. 2005; Park, Thomson, and Clandinin).

One source of a variety of dietary sphingolipids is MFGM. The phospholipids and membrane glycoproteins found in MFGM likely interact extensively with the gut epithelia during digestion, both physically and biochemically. Its unique composition has led to the idea that MFGM could have remarkable nutraceutical properties (Spitsberg 2005), and various research groups are conducting studies to ease its recovery from buttermilk (Astaire et al. 2003; Corredig, Roesch, and Dalgleish 2003; Morin et al. 2007; Morin, Jimenez-Flores, and Pouliot 2006; Morin, Pouliot, and Jimenez-Flores 2006; Rombaut, Dejonckheere, and Dewettinck 2006, 2007; Rombaut and Dewettinck 2007; Spence et al. 2005; Spence et al. 2009, 2009).

Although MFGM's recovery is well documented, very few studies have been conducted to determine any nutritional benefits of MFGM, although some indicate beneficial effects of its components. One study demonstrated that milk fat globule-EGF factor-8/lactadherin, a major protein component associated with MFGM, is an important factor in maintaining epithelial homeostasis and mucosal integrity of the intestinal tract (Bu et al. 2007), and other groups have demonstrated the MFGM-derived polar lipids improve the resistance of epithelia to stress (Dial and Lichtenberger 1987; Kivinen et al. 1995).

We investigated whether diets containing MFGM will promote gut mucosal integrity in BALB/c mice challenged with lipopolysaccharide (LPS). LPS induces an inflammatory response mimicking gastrointestinal injury (Zayat, Lichtenberger, and Dial 2008), and has been used in numerous studies to emulate the inflammatory response seen in gram negative bacterial infections. Because of MFGM's phospholipid enrichment and unique biochemical nature, we hypothesized that diets providing MFGM as a fat source might protect against an exaggerated inflammatory response and corresponding compromised gut barrier integrity.

\subsection{Experimental design}

Diets were formulated to differ only in the composition of the fat. The control diet contained $5 \%$ fat provided as corn oil. The MFGM diet also contained 5\% fat, but half of the fat for the MFGM diet was provided as anhydrous milk fat and half was provided as MFGM isolate. MFGM isolate is approximately $60 \%$ triglycerides and $40 \%$ polar lipids. Besides dietary fat source, both diets were identical in macro and micro nutrients. The measurement of protein, total fat, ash and lactose were conducted as previously described (Spence et al. 2009). Ash was further analyzed for specific minerals by inductively coupled plasma spectroscopy (ICP-AES) at a core facility on the USU campus.

To test the hypothesis that MFGM confers protective effects against LPS induced inflammation and improves gut barrier protection; a $2 \times 2$ factorial design was used. Weanling, male BALB/c mice ( $n=24 /$ time point) were randomly assigned to one of the following treatments: 1) control diet (AIN-76A), saline vehicle control injection $(n=6) ; 2$ ) control diet, LPS injection ( $\mathrm{n}=6)$; 3) MFGM diet (AIN-76A with milk fat), saline vehicle control injection $(n=6)$; or 4) MFGM diet, LPS injection $(n=6)$ (Figure 6). Mice were fed experimental diets for five weeks. This timeframe is precedented by a previous investigation examining dietary Zn and LPS induced inflammation (Peterson et al. 2008). On day 35, Mice were injected intraperitoneally (i.p.) with a dose of saline vehicle control or 
LPS (10 mg/ kg body weight) known to induce inflammatory cytokines and compromise gut barrier integrity. This dose of LPS (i.p.) has previously been shown to induce monocyte adhesion and infiltration into intestinal tissues of mice and induce intestinal distress (Peterson et al. 2008). To assess intestinal permeability, mice were gavaged with $4000 \mathrm{Da}$ Dextran-FITC (Sigma) suspended in PBS immediately after vehicle control or LPS injection (Krimsky et al. 2000). After injection and gavage, animals were serially harvested at $24 \mathrm{~h}$ and $48 \mathrm{~h}$ by $\mathrm{CO}_{2}$ asphyxiation. In a preliminary study we saw no changes in the appearance of plasma fluorescence after LPS injection at 0 and $12 \mathrm{~h}$ with peak fluorescence occurring at $24 \mathrm{~h}$ (data not shown). These time points and animal numbers have been used successfully to determine statistical differences in membrane integrity (Krimsky et al. 2000). Serum, liver, femur, and muscle samples were taken and stored for future analysis.

To assess gut barrier integrity, serum samples from all time points were assayed for dextranFITC (Amersham Typhoon Trio+ ${ }^{\circledR}$ and ImageQuant ${ }^{\circledR}$ TL software, GE Healthcare BioSciences, Uppsala, Sweden). Dextran-FITC permeation of the gut has shown to be a sensitive indicator of gut barrier integrity in vivo and serum dextran-FITC levels are positively correlated with intestinal insult (Krimsky et al. 2000).

Serum cytokine analysis was performed on samples from all time points using the Q-Plex ${ }^{\mathrm{TM}}$ Mouse Cytokine - Screen (16-plex) array (Quansys Biosciences, Logan, UT, USA). Cytokines analyzed include: IL-1 $\alpha$, IL-1 $\beta$, IL-2, IL-3, IL-4, IL-5, IL-6, IL-10, IL-12p70, IL-17, MCP-1, IFN $\gamma$, TNF $\alpha$, MIP-1 $\alpha$, GMCSF, and RANTES. LPS has been shown to elevate serum concentrations of various cytokines in mice, specifically IL-6, IL-10, IL-12, MCP-1, IFN $\gamma$, and TNF $\alpha$ (Nandi et al. 2009).

\subsection{Effect of MFGM on gut permeability}

Analysis of dextran-FITC levels in serum showed that gut permeability decreased significantly at $24 \mathrm{~h}$ in animals fed MFGM diet (MFGM diet/LPS/24h: $5.92 \pm 0.59 \mu \mathrm{g} / \mathrm{mL}$ ) versus control diet (control diet/LPS/24h: $10.8 \pm 0.18 \mu \mathrm{g} / \mathrm{mL} ; P<0.05$ ) when challenged with LPS, which is a $45 \%$ decrease. Animals injected with the vehicle control had the same serum

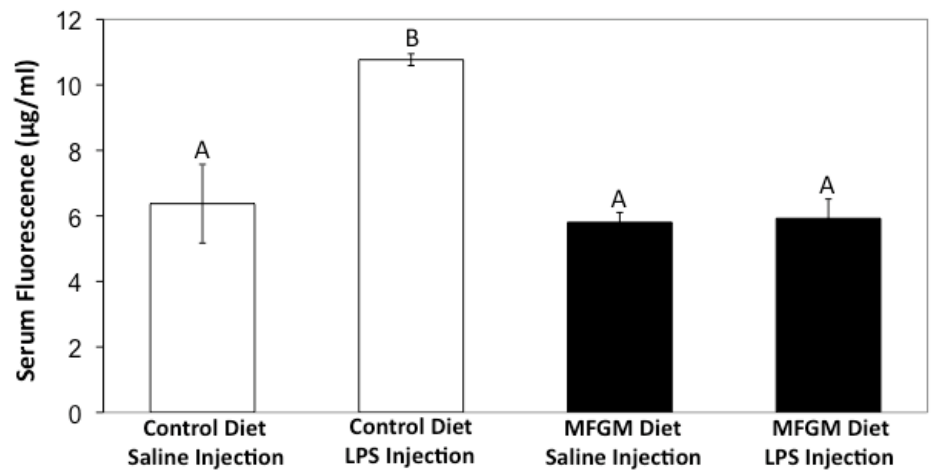

Fig. 6. Effect of experimental diets and treatments on gut permeability at $24 \mathrm{~g}$. Serum fluorescence levels of LPS challenged mice fed MFGM diet did not differ significantly from those receiving vehicle injection but were significantly lower $(P<0.05)$ than LPS challenged mice fed control diet at $24 \mathrm{~h}$. Data are mean dextran-FITC concentrations \pm standard deviations. Differently labeled columns are significantly different $(P<0.05)$. 
fluorescence levels of LPS challenged animals fed the MFGM diet at 24 and $48 \mathrm{~h}$ (control diet/saline/24h: $6.37 \pm 1.29 \mu \mathrm{g} / \mathrm{mL}$; control diet/saline/48h: $5.63 \pm 0.39 \mu \mathrm{g} / \mathrm{mL} ; \mathrm{MFGM}$ diet/saline/24h: $5.80 \pm 0.31 \mu \mathrm{g} / \mathrm{mL}$; MFGM diet/saline/48h: $5.75 \pm 0.46 \mu \mathrm{g} / \mathrm{mL}$; MFGM diet/LPS/48h: $5.68 \pm 0.55 \mu \mathrm{g} / \mathrm{mL}$ ). All animals fed control diet and challenged with LPS died before the $48 \mathrm{~h}$ time point. Serum fluorescence of animals fed control diet and challenged with LPS was significantly higher than animals fed MFGM diet and challenged with LPS, illustrating that MFGM plays a role in protecting against gastrointestinal injury. Also, animals fed MFGM diet and challenged with LPS had serum fluorescence levels that did not differ significantly from animals fed control and MFGM diets receiving vehicle injections, (Figure 6) further demonstrating MFGM's protective effect on gut barrier integrity.

\subsection{Effect of MFGM on serum cytokines}

At the $24 \mathrm{~h}$ time point, six of the 16 total cytokines had a significantly lower serum concentration among animals fed the MFGM diet versus the control diet. IL-6 was the most significant difference $(2.24 \mathrm{pg} / \mathrm{mg}$ serum protein $\pm 0.34 \mathrm{vs} .4 .00 \mathrm{pg} / \mathrm{mg}$ serum protein \pm 0.42 ; $P<0.002)$. Other serum cytokine concentrations that were significantly lower were IL-10 $(3.12 \mathrm{fg} / \mathrm{mg}$ serum protein \pm 0.04 vs. $3.61 \mathrm{fg} / \mathrm{mg}$ serum protein $\pm 0.30 ; P<0.04) ;$ IL-17 $(2.79$ $\mathrm{fg} / \mathrm{mg}$ serum protein \pm 0.60 vs. $3.71 \mathrm{fg} / \mathrm{mg}$ serum protein $\pm 0.64 ; P<0.03) ; \mathrm{MCP}-1$ (1.90 $\mathrm{pg} / \mathrm{mg}$ serum protein $\pm 0.67 \mathrm{vs} .3 .07 \mathrm{pg} / \mathrm{mg}$ serum protein $\pm 0.83 ; P<0.05) ; \operatorname{IFN} \gamma(2.87 \mathrm{fg} / \mathrm{mg}$ serum protein \pm 0.29 vs. $4.13 \mathrm{fg} / \mathrm{mg}$ serum protein $\pm 0.61 ; P<0.025) ; \mathrm{TNF} \alpha(2.47 \mathrm{fg} / \mathrm{mg}$ serum protein \pm 0.12 vs. $3.21 \mathrm{fg} / \mathrm{mg}$ serum protein $\pm 0.40 ; P<0.03)$; and IL-12p70 (2.67 fg/mg serum protein \pm 0.02 vs. $3.52 \mathrm{fg} / \mathrm{mg}$ serum protein $\pm 0.24 ; P<0.002)$. Serum concentrations of IL-3 were below the detection limit at $24 \mathrm{~h}$ and $48 \mathrm{~h}$. Serum cytokines did not differ significantly in any of the following cytokines at $24 \mathrm{~h}$ : IL-1 $\alpha$, IL-1 $\beta$, IL-5, MIP-1 $\alpha$, GMCSF, and RANTES. Cytokines IL-2 and IL-4 were not affected by LPS challenge (For summary see Table 4 ).

\begin{tabular}{|l|l|}
\hline Cytokine & $\begin{array}{l}\text { Effect of Diet on Serum Cytokine Concentrations } 24 \text { hours post } 5 \mathbf{~ m g} / \mathbf{k g} \\
\text { bodyweight LPS Challenge }\end{array}$ \\
\hline GMCSF & No difference between control and MFGM dietary treatments \\
\hline IL-1 $\alpha$ & No difference between control and MFGM dietary treatments \\
\hline IL1- $\beta$ & No difference between control and MFGM dietary treatments \\
\hline IL-3 & Below detection limit in MFGM dietary treatment \\
\hline IL-5 & No difference between control and MFGM dietary treatments \\
\hline IL-6 & Significantly lower in MFGM dietary treatment compared to control $(P<0.005)$ \\
\hline IL-10 & Significantly lower in MFGM dietary treatment compared to control $(P<0.05)$ \\
\hline IL-12p70 & Significantly lower in MFGM dietary treatment compared to control $(P<0.005)$ \\
\hline IL-17 & Significantly lower in MFGM dietary treatment compared to control $(P<0.05)$ \\
\hline INF $\gamma$ & Significantly lower in MFGM dietary treatment compared to control $(P<0.05)$ \\
\hline MCP-1 & Significantly lower in MFGM dietary treatment compared to control $(P<0.05)$ \\
\hline MIP-1 & No difference between control and MFGM dietary treatments \\
\hline RANTES & No difference between control and MFGM dietary treatments \\
\hline TNF- $\alpha$ & Significantly lower in MFGM dietary treatment compared to control $(P<0.05)$ \\
\hline
\end{tabular}

Table 4. Significant effects of dietary treatment on serum cytokine levels after LPS challenge at $24 \mathrm{~h}$. 


\subsection{Summary}

During inflammation, cytokines are released in response to trauma as represented by the control diet with LPS challenge. The decreased serum levels of several cytokines in mice fed the experimental diet suggest that MFGM reduces the inflammatory response following stress. Our results are consistent with those investigating the effects of sphingolipids and gangliosides on inflammation (Dalbeth et al. 2009; El Alwani et al. 2006; Park et al. 2007; Park et al. 2005), suggesting that the high sphingolipid content of MFGM could be responsible for the lowered inflammatory response.

Gut barrier dysfunction has been identified as a result of cytokine induction due to inflammation (Sun et al. 1999). As adhesion molecules are expressed on the endothelial membrane surface, inflammatory mediators are produced and released which compromise gut barrier integrity by interacting with the circulating leukocytes (Formela, Galloway, and Kingsnorth 1995). Our results suggest that MFGM as a dietary component plays a role in protecting against intestinal permeability by controlling the inflammatory response, causing the gut barrier to remain better intact.

In conclusion, after treatment with LPS, we saw that MFGM dietary treatment led to a $45 \%$ decrease in gut permeability and significant differences of serum cytokine levels in eight of the 16 cytokines analyzed when compared to control dietary treatment. Our results imply that MFGM, a by-product of dairy processing, is protective against gastrointestinal stress. Possible mechanisms for its protection are the increased polar lipid content of the MFGM diet and the inhibition of several cytokines during the inflammatory response, leading to increased gut barrier integrity.

\section{Conclusion}

MFGM is a complex biopolymer. It contains various protein and lipid components that have been shown to exhibit beneficial properties in the gut. To date, no other studies have examined the effects of dietary MFGM as a whole dietary component on cancer, gut permeability and inflammation, contributing to the novelty of these studies.

The results of these studies support the hypothesis that dietary MFGM protects against colon cancer in rats. Although no differences were seen in candidate carcinogenesis gene mRNA levels by microarray analysis, we cannot rule out the suggestion that MFGM affects gene regulation. A recent study demonstrated that sphingomyelin (a major component of MFGM) did not alter mRNA levels but had a significant effect on protein levels of genes critical to the early stages of colon cancer (Simon et al. 2009). Animals receiving the MFGM dietary treatment were provided with three to four times the amount of sphingomyelin compared to animals receiving control or AMF dietary treatments $(0.11 \%$ vs. $0.03 \% \mathrm{w} / \mathrm{w})$. The high polar lipid content and unique protein profile of MFGM likely contributed to the beneficial effects.

The results of this study also support the hypothesis that dietary MFGM protects against gastrointestinal stress in mice and cultured Caco2 cells. Gut permeability, a common condition during gastrointestinal stress, was significantly lower in MFGM treated Caco-2 cells challenged with EGTA and animals challenged with LPS receiving the MFGM dietary treatment compared with those receiving control dietary treatment. This effect is most likely due to the inhibition of the inflammatory response seen in animals receiving the MFGM dietary treatment, although the mechanism of how dietary MFGM inhibited the inflammatory response is not yet understood. Many of the polar lipids and proteins found 
in MFGM have been shown to encourage mucosal integrity, maintain epithelial homeostasis and improve the resistance of epithelia to stress; therefore, MFGM's high polar lipid content and unique protein profile likely contribute to its decrease in gut permeability.

Through the course of these studies, we have demonstrated that MFGM can be incorporated into diets. And, as a dietary component, MFGM plays a role in a protection mechanism against colon cancer and gastrointestinal stress.

\section{References}

Adkins, Y., and B. Lonnerdal. 2003. Potential host-defense role of a human milk vitamin B12-binding protein, haptocorrin, in the gastrointestinal tract of breastfed infants, as assessed with porcine haptocorrin in vitro. Am JClin Nutr 77 (5):1234-40.

Affolter, Michael, Laetitia Grass, Frank Vanrobaeys, Begoña Casado, and Martin Kussmann. 2010. Qualitative and quantitative profiling of the bovine milk fat globule membrane proteome. eburnal of Proteomics 73 (6):1079-1088.

Astaire, J. C., R. Ward, J. B. German, and R. Jimenez-Flores. 2003. Concentration of polar MFGM lipids from buttermilk by microfiltration and supercritical fluid extraction. eburnal of Dairy Science 86 (7):2297-2307.

Bernback, S., L. Blackberg, and O. Hernell. 1990. The complete digestion of human milk triacylglycerol in vitro requires gastric lipase, pancreatic colipase-dependent lipase, and bile salt-stimulated lipase. JClin Invest 85 (4):1221-6.

Blikslager, A. T., M. C. Roberts, and R. A. Argenzio. 1999. Prostaglandin-induced recovery of barrier function in porcine ileum is triggered by chloride secretion. Am JPhysiol 276 (1 Pt 1):G28-36.

Brisson, Guillaume, Hannah F. Payken, John P. Sharpe, and Rafael Jiménez-Flores. 2010. Characterization of Lactobacillus reuteri Interaction with Milk Fat Globule Membrane Components in Dairy Products. eburnal of Agricultural and Food Chemistry 58 (9):5612-5619.

Bu, H. F., X. L. Zuo, X. Wang, M. A. Ensslin, V. Koti, W. Hsueh, A. S. Raymond, B. D. Shur, and X. D. Tan. 2007. Milk fat globule-EGF factor 8/lactadherin plays a crucial role in maintenance and repair of murine intestinal epithelium. J Clin Invest 117 (12):3673-83.

Cavaletto, M., M. G. Giuffrida, and A. Conti. 2004. The proteomic approach to analysis of human milk fat globule membrane. Clin Chim Acta 347 (1-2):41-8.

Cavaletto, M., M.G. Giuffrida, M. G. and A. Conti. 2008. Milk fat globule membrane components--a proteomic approach. Adv Exp Med Biol 606:129-41.

Cavaletto, M., M. G. Giuffrida, D. Fortunato, L. Gardano, G. Dellavalle, L. Napolitano, C. Giunta, E. Bertino, C. Fabris, and A. Conti. 2002. A proteomic approach to evaluate the butyrophilin gene family expression in human milk fat globule membrane. Proteomics 2 (7):850-6.

Cebo, C., H. Caillat, F. Bouvier, and P. Martin. 2010. Major proteins of the goat milk fat globule membrane. eburnal of Dairy Science 93 (3):868-876.

Clare, D. A., Z. Zheng, H. M. Hassan, H. E. Swaisgood, and G. L. Catignani. 2008. Antimicrobial properties of milkfat globule membrane fractions. J Food Prot 71 (1):126-33.

Clark, A. G., S. Glanowski, R. Nielsen, P. D. Thomas, A. Kejariwal, M. A. Todd, D. M. Tanenbaum, D. Civello, F. Lu, B. Murphy, S. Ferriera, G. Wang, X. Zheng, T. J. 
White, J. J. Sninsky, M. D. Adams, and M. Cargill. 2003. Inferring nonneutral evolution from human-chimp-mouse orthologous gene trios. Science 302 (5652):1960-3.

Corredig, M., R. R. Roesch, and D. G. Dalgleish. 2003. Production of a novel ingredient from buttermilk. JDairy Sci 86 (9):2744-50.

Coyle, P., J. C. Philcox, L. C. Carey, and A. M. Rofe. 2002. Metallothionein: the multipurpose protein. Cell Mol Life Sci 59 (4):627-47.

Dahm, F., A. Bielawska, A. Nocito, P. Georgiev, Z. M. Szulc, J. Bielawski, W. Jochum, D. Dindo, Y. A. Hannun, and P. A. Clavien. 2008. Mitochondrially targeted ceramide LCL-30 inhibits colorectal cancer in mice. Br JCancer 98 (1):98-105.

Dalbeth, N., E. Gracey, B. Pool, K. Callon, F. M. McQueen, J. Cornish, A. McGibbon, and K. Palmano. 2009. Identification of dairy fractions with anti-inflammatory properties in models of acute gout. Ann Rheum Dis.

Damodaran, Srinivasan. 2010. Zinc-Induced Precipitation of Milk Fat Globule Membranes: A Simple Method for the Preparation of Fat-Free Whey Protein Isolate. eburnal of Agricultural and Food Chemistry 58 (20):11052-11057.

Dial, E. J., and L. M. Lichtenberger. 1987. Milk protection against experimental ulcerogenesis in rats. Dig Dis Sci 32 (10):1145-50.

Dillehay, D. L., S. K. Webb, E. M. Schmelz, and A. H. Merrill, Jr. 1994. Dietary sphingomyelin inhibits 1,2-dimethylhydrazine-induced colon cancer in CF1 mice. $J$ Nutr 124 (5):615-20.

Dindo, D., F. Dahm, Z. Szulc, A. Bielawska, L. M. Obeid, Y. A. Hannun, R. Graf, and P. A. Clavien. 2006. Cationic long-chain ceramide LCL-30 induces cell death by mitochondrial targeting in SW403 cells. Mol Cancer Ther 5 (6):1520-9.

Doll, R., and R. Peto. 1981. The causes of cancer: quantitative estimates of avoidable risks of cancer in the United States today. JNatl Cancer Inst 66 (6):1191-308.

Duan, R. D., and A. Nilsson. 2009. Metabolism of sphingolipids in the gut and its relation to inflammation and cancer development. Prog Lipid Res 48 (1):62-72.

El Alwani, M., B. X. Wu, L. M. Obeid, and Y. A. Hannun. 2006. Bioactive sphingolipids in the modulation of the inflammatory response. Pharmacol Ther 112 (1):171-83.

Fink, M. P. 2003. Intestinal epithelial hyperpermeability: update on the pathogenesis of gut mucosal barrier dysfunction in critical illness. Curr Opin Crit Care 9 (2):143-51.

Finley, J. W., C. Ip, D. J. Lisk, C. D. Davis, K. J. Hintze, and P. D. Whanger. 2001. Cancerprotective properties of high-selenium broccoli. JAgric Food Chem 49 (5):2679-83.

Folch, J., M. Lees, and G. H. Sloane Stanley. 1957. A simple method for the isolation and purification of total lipides from animal tissues. JBiol Chem 226 (1):497-509.

Fong, B. Y., and C. S. Norris. 2009. Quantification of milk fat globule membrane proteins using selected reaction monitoring mass spectrometry. J Agric Food Chem 57 (14):6021-8.

Fong, BY, CS Norris, and AKH MacGibbon. 2007. Protein and lipid composition of bovine milk-fat-globule membrane. International Dairy eburnal 17 (4):275-88.

Formela, L. J., S. W. Galloway, and A. N. Kingsnorth. 1995. Inflammatory mediators in acute pancreatitis. Br JSurg 82 (1):6-13.

German, J. B., and C. J. Dillard. 2006. Composition, structure and absorption of milk lipids: a source of energy, fat-soluble nutrients and bioactive molecules. Crit Rev Food Sci Nutr 46 (1):57-92. 
German, J. B., C. J. Dillard, and R. E. Ward. 2002. Bioactive components in milk. Current Opinion in Clinical Nutrition and Metabolic Care 5 (6):653-658.

Gupta, N., P. Rathi, and R. Gupta. 2002. Simplified para-nitrophenyl palmitate assay for lipases and esterases. Anal Biochem 311 (1):98-9.

Hamosh, M., D. Ganot, and P. Hamosh. 1979. Rat lingual lipase. Characteristics of enzyme activity. JBiol Chem 254 (23):12121-5.

Jayadev, S., C. M. Linardic, and Y. A. Hannun. 1994. Identification of arachidonic acid as a mediator of sphingomyelin hydrolysis in response to tumor necrosis factor alpha. $J$ Biol Chem 269 (8):5757-63.

Jovov, B, NK WIlls, and SA Lewis. 1991. A spectroscopic method for assessing confluence of epithelial cell cultures. amj physiol cell physiol 261 (6):C1196-C1203.

Keenan, T.W., and S. Patton. 1995. The structure of milk: implications for sampling and storage A. The milk lipid globular membrane. In Handbook of Milk Composition, edited by R. G. Jensen. San Diego: Academic Press.

Kivinen, A., S. Tarpila, T. Kiviluoto, H. Mustonen, and E. Kivilaakso. 1995. Milk and egg phospholipids act as protective surfactants against luminal acid in Necturus gastric mucosa. Aliment Pharmacol Ther 9 (6):685-91.

Krimsky, M., A. Dagan, L. Aptekar, M. Ligumsky, and S. Yedgar. 2000. Assessment of intestinal permeability in rats by permeation of inulin-fluorescein. J Basic Clin Physiol Pharmacol 11 (2):143-53.

Lemonnier, L. A., D. L. Dillehay, M. J. Vespremi, J. Abrams, E. Brody, and E. M. Schmelz. 2003. Sphingomyelin in the suppression of colon tumors: prevention versus intervention. Arch Biochem Biophys 419 (2):129-38.

Lewis, K., and D. M. McKay. 2009. Metabolic stress evokes decreases in epithelial barrier function. Ann N Y Acad Sci 1165:327-37.

MacGibbon, AKH, and MW Taylor. 2006. Composition and Structure of Bovine Milk Lipids. In Advanced Dairy Chemistry Lipids, edited by P. F. Fox and P. L. H. McSweeney. New York: Springer.

Morin, P., M. Britten, R. Jimenez-Flores, and Y. Pouliot. 2007. Microfiltration of buttermilk and washed cream buttermilk for concentration of milk fat globule membrane components. JDairy Sci 90 (5):2132-40.

Morin, P., R. Jimenez-Flores, and Y. Pouliot. 2006. Effect of processing on the composition and structure of buttermilk and of its milk fat globule membranes. eburnal of Animal Science 84:317-317.

Morin, P., Y. Pouliot, and R. Jimenez-Flores. 2006. A comparative study of the fractionation of regular buttermilk and whey buttermilk by microfiltration. cburnal of Food Engineering 77 (3):521-528.

Nandi, D., M. K. Mishra, A. Basu, and B. Bishayi. 2009. Protective effects of interleukin-6 in lipopolysaccharide (LPS)-induced experimental endotoxemia are linked to alteration in hepatic anti-oxidant enzymes and endogenous cytokines. Immunobiology.

Nilsson, A., and R. D. Duan. 2006. Absorption and lipoprotein transport of sphingomyelin. $J$ Lipid Res 47 (1):154-71.

Park, E. J., M. Suh, B. Thomson, D. W. Ma, K. Ramanujam, A. B. Thomson, and M. T. Clandinin. 2007. Dietary ganglioside inhibits acute inflammatory signals in 
intestinal mucosa and blood induced by systemic inflammation of Escherichia coli lipopolysaccharide. Shock 28 (1):112-7.

Park, E. J., M. Suh, B. Thomson, A. B. Thomson, K. S. Ramanujam, and M. T. Clandinin. 2005. Dietary ganglioside decreases cholesterol content, caveolin expression and inflammatory mediators in rat intestinal microdomains. Glycobiology 15 (10):935-42.

Park, E. J., A. B. Thomson, and M. T. Clandinin. Protection of intestinal occludin tight junction protein by dietary gangliosides in lipopolysaccharide-induced acute inflammation. JPediatr Gastroenterol Nutr 50 (3):321-8.

Peterson, D. G., A. G. Scrimgeour, J. P. McClung, and E. A. Koutsos. 2008. Moderate zinc restriction affects intestinal health and immune function in lipopolysaccharidechallenged mice. JNutr Biochem 19 (3):193-9.

Pisanu, Salvatore, Stefania Ghisaura, Daniela Pagnozzi, Grazia Biosa, Alessandro Tanca, Tonina Roggio, Sergio Uzzau, and Maria Filippa Addis. 2011. The sheep milk fat globule membrane proteome. eburnal of Proteomics 74 (3):350-358.

Pretlow, T. P., M. A. O'Riordan, G. A. Somich, S. B. Amini, and T. G. Pretlow. 1992. Aberrant crypts correlate with tumor incidence in F344 rats treated with azoxymethane and phytate. Carcinogenesis 13 (9):1509-12.

Prosser, C., K. Stelwagen, R. Cummins, P. Guerin, N. Gill, and C. Milne. 2004. Reduction in heat-induced gastrointestinal hyperpermeability in rats by bovine colostrum and goat milk powders. JAppl Physiol 96 (2):650-4.

Reinhardt, T. A., and J. D. Lippolis. 2006. Bovine milk fat globule membrane proteome. $J$ Dairy Res 73 (4):406-16.

Rombaut, R., V. Dejonckheere, and K. Dewettinck. 2006. Microfiltration of butter serum upon casein micelle destabilization. JDairy Sci 89 (6):1915-25.

Cavaletto, M., M.G., Giuffrida and A. Conti. 2007. Filtration of milk fat globule membrane fragments from acid buttermilk cheese whey. JDairy Sci 90 (4):1662-73.

Rombaut, R., and K. Dewettinck. 2007. Thermocalcic aggregation of milk fat globule membrane fragments from acid buttermilk cheese whey. JDairy Sci 90 (6):2665-74.

Ruegg, M., and B. Blanc. 1981. The fat globule size distribution in human milk. Biochim. Biophys. Acta 666:7-14.

Schmelz, E. M., D. L. Dillehay, S. K. Webb, A. Reiter, J. Adams, and A. H. Merrill, Jr. 1996. Sphingomyelin consumption suppresses aberrant colonic crypt foci and increases the proportion of adenomas versus adenocarcinomas in CF1 mice treated with 1,2dimethylhydrazine: implications for dietary sphingolipids and colon carcinogenesis. Cancer Res 56 (21):4936-41.

Schmelz, E. M., M. C. Sullards, D. L. Dillehay, and A. H. Merrill, Jr. 2000. Colonic cell proliferation and aberrant crypt foci formation are inhibited by dairy glycosphingolipids in 1, 2-dimethylhydrazine-treated CF1 mice. JNutr 130 (3):5227.

Simon, K. W., P. C. Roberts, M. J. Vespremi, S. Manchen, and E. M. Schmelz. 2009. Regulation of beta-catenin and connexin- 43 expression: targets for sphingolipids in colon cancer prevention. Mol Nutr FoodRes 53 (3):332-40.

Smolenski, G., S. Haines, F. Y. Kwan, J. Bond, V. Farr, S. R. Davis, K. Stelwagen, and T. T. Wheeler. 2007. Characterisation of host defence proteins in milk using a proteomic approach. JProteome Res 6 (1):207-15. 
Snow, D. R., R. Jimenez-Flores, R. E. Ward, J. Cambell, M. J. Young, I. Nemere, and K. J. Hintze. Dietary milk fat globule membrane reduces the incidence of aberrant crypt foci in Fischer-344 rats. JAgric Food Chem 58 (4):2157-63.

Society, American Cancer. 2009. Cancer Facts \& Figures 2009. Atlanta: American Cancer Society.

Spence, A. J., R. Jimenez-Flores, M. Qian, and L. Goddik. 2009. Phospholipid enrichment in sweet and whey cream buttermilk powders using supercritical fluid extraction. eburnal of Dairy Science 92 (6):2373-2381.

Spence, A. J., R. Jimenez-Flores, M. Qia and L. Goddik. 2009. The influence of temperature and pressure factors in supercritical fluid extraction for optimizing nonpolar lipid extraction from buttermilk powder. JDairy Sci 92 (2):458-68.

Spence, A., J. Yee, M. Qian, and R. Jimenez-Flores. 2005. Concentration of polar MFGM lipids from buttermilk using supercritical carbon dioxide. eburnal of Animal Science 83:144-144.

Spitsberg, V. L. 2005. Invited review: Bovine milk fat globule membrane as a potential nutraceutical. JDairy Sci 88 (7):2289-94.

Spitsberg, V.L. 2005. Invited Review: Bovine Milk Fat Globule Membrane as a Potential Nutraceutical. el Dairy Sci 88:2289-2294.

Sun, Z., X. Wang, A. Lasson, A. Borjesson, P. Leveau, P. Haraldsen, and R. Andersson. 1999. Roles of platelet-activating factor, interleukin-1beta and interleukin- 6 in intestinal barrier dysfunction induced by mesenteric arterial ischemia and reperfusion. JSurg Res 87 (1):90-100.

Tudek, B., R. P. Bird, and W. R. Bruce. 1989. Foci of aberrant crypts in the colons of mice and rats exposed to carcinogens associated with foods. Cancer Res 49 (5):1236-40.

Vorbach, C., M. R. Capecchi, and J. M. Penninger. 2006. Evolution of the mammary gland from the innate immune system? Bioessays 28 (6):606-16.

Ward, R. E., and J. B. German. 2004. Understanding milk's bioactive components: a goal for the genomics toolbox. JNutr 134 (4):962S-7S.

Ward, R. E., J.B. German, and M Corredig. 2005. Composition, applications, fractionation, technological and nutritional significance of milk fat globule membrane material. In Advanced Dairy Chemistry-2. Lipids, edited by P. F. Fox and P. L. H. McSweeney. New York: Klewer Academic Publishers.

Ward, R. E., H. J. Watzke, R. Jimenez-Flores, and J. B. German. 2004. Bioguided processing: A paradigm change in food production. Food Technology 58 (5):44-48.

Yajima, S., H. Morisaki, R. Serita, T. Suzuki, N. Katori, T. Asahara, K. Nomoto, F. Kobayashi, A. Ishizaka, and J. Takeda. 2009. Tumor necrosis factor-alpha mediates hyperglycemia-augmented gut barrier dysfunction in endotoxemia. Crit Care Med 37 (3):1024-30.

Zayat, M., L. M. Lichtenberger, and E. J. Dial. 2008. Pathophysiology of LPS-induced gastrointestinal injury in the rat: role of secretory phospholipase A2. Shock 30 (2):206-11. 


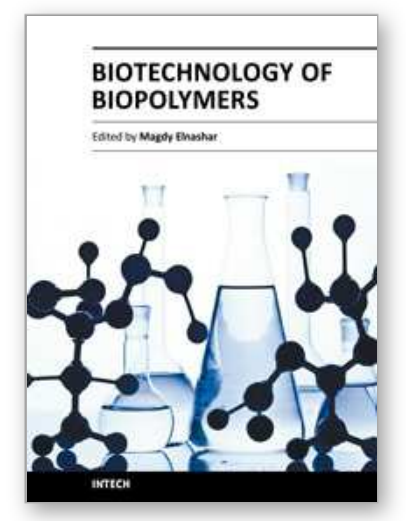

\author{
Biotechnology of Biopolymers \\ Edited by Prof. Magdy Elnashar
}

ISBN 978-953-307-179-4

Hard cover, 364 pages

Publisher InTech

Published online 24, June, 2011

Published in print edition June, 2011

The book "Biotechnology of Biopolymers" comprises 17 chapters covering occurrence, synthesis, isolation and production, properties and applications, biodegradation and modification, the relevant analysis methods to reveal the structures and properties of biopolymers and a special section on the theoretical, experimental and mathematical models of biopolymers. This book will hopefully be supportive to many scientists, physicians, pharmaceutics, engineers and other experts in a wide variety of different disciplines, in academia and in industry. It may not only support research and development but may be also suitable for teaching. Publishing of this book was achieved by choosing authors of the individual chapters for their recognized expertise and for their excellent contributions to the various fields of research.

\title{
How to reference
}

In order to correctly reference this scholarly work, feel free to copy and paste the following:

Korry J. Hintze, Dallin Snow, lan Burtenshaw and Robert E. Ward (2011). Nutraceutical Properties of Milk Fat Globular Membrane, Biotechnology of Biopolymers, Prof. Magdy Elnashar (Ed.), ISBN: 978-953-307-179-4, InTech, Available from: http://www.intechopen.com/books/biotechnology-of-biopolymers/nutraceuticalproperties-of-milk-fat-globular-membrane

\section{INTECH}

open science | open minds

\section{InTech Europe}

University Campus STeP Ri

Slavka Krautzeka 83/A

51000 Rijeka, Croatia

Phone: +385 (51) 770447

Fax: +385 (51) 686166

www.intechopen.com

\section{InTech China}

Unit 405, Office Block, Hotel Equatorial Shanghai

No.65, Yan An Road (West), Shanghai, 200040, China

中国上海市延安西路65号上海国际贵都大饭店办公楼 405 单元

Phone: +86-21-62489820

Fax: +86-21-62489821 
(C) 2011 The Author(s). Licensee IntechOpen. This chapter is distributed under the terms of the Creative Commons Attribution-NonCommercialShareAlike-3.0 License, which permits use, distribution and reproduction for non-commercial purposes, provided the original is properly cited and derivative works building on this content are distributed under the same license. 